\title{
Capnocytophaga sputigena Bacteremia Associated with Acute Leukemia
}

\author{
Hisashi FUNADA ${ }^{1)}$, Toshihiko MACHI'), Hiroshi YONEYAMA ${ }^{11}$, Tamotsu MATSUDA ${ }^{11}$, \\ Hiroaki MIURA ${ }^{2)}$, Takayuki EZAKI' ${ }^{2)}$ and Yoshiko YOKOTA ${ }^{3)}$ \\ 1)Protected Environment Unit and Third Department of Medicine, Kanazawa University \\ School of Medicine, Kanazawa 920, Japan \\ ${ }^{2}$ Department of Microbiology, Gifu University School of Medicine, Gifu 500, Japan \\ 3)Product Development Laboratories, Fujisawa Pharmaceutical Co., Ltd., Osaka 532, Japan \\ (Received: November 24, 1992) \\ (Accepted: March 29, 1993)
Key words: Capnocytophaga sputigena bacteremia, acute leukemia, cancer chemotherapy, orodental infection, deoxyribonucleic acid (DNA) homology

\begin{abstract}
During a three-year period, Capnocytophaga sputigena bacteremia occurred in three patients with acute leukemia receiving induction therapy on a hematology ward. Oral pathology such as periodontitis or severe mucositis was considered to be the most likely source of bacteremia. All three blood culture isolates were identified as that species by deoxyribonucleic acid (DNA) homology studies. Because of the phenotypical similarity of Capnocytophaga species, it is difficult to differentiate them by conventional bacteriological methods. All three isolates were susceptible to antibiotics active against most anaerobes. However, production of $\beta$-lactamase was found in two isolates, one of which proved resistant to both piperacillin and ceftazidime. Therefore, the empiric use of imipenem or clindamycin may be justified in febrile granulocytopenic patients with cancer who develop significant oral lesions.
\end{abstract}

\section{Introduction}

The genus Capnocytophaga is part of the normal oral microflora ${ }^{1 / 3)}$. The organisms have been incriminated as major pathogens in oral pathology such as periodontitis or mucositis ${ }^{2 \sim 5)}$. Capnocytophaga bacteremia has recently been reported to occur with increasing frequency in granulocytopenic patients, particularly in those with acute leukemia receiving intensive chemotherapy or in those undergoing bone marrow transplantation ${ }^{4,5)}$. Indeed, some of the recent bacteremias have originated from the oropharynx, although the gastrointestinal tract has been the most common source of bacteremia ${ }^{4,6) 88}$.

We describe here three cases of Capnocytophaga sputigena bacteremia associated with acute leukemia, focusing on the role of oral pathology as the portal of entry and on the genomic speciation of blood culture isolates as well as on the clinical significance of their $\beta$-lactamase-producing ability.

\section{Outline of Cases}

During a three-year period, 1989-1991, we experienced three cases of C. sputigena bacteremia in a similar clinical setting at the Third Department of Medicine, Kanazawa University Hospital (Table 1). Three women were admitted for evaluation and treatment of acute leukemia. They became febrile during

\footnotetext{
別刷請求先：（广920）金沢市宝町13番 1 号 金沢大学医学部附属病院高密度無菌治療 部 舟田 久
} 
Table 1 Clinical summary of patients with $C$. sputigena bacteremia

\begin{tabular}{|c|c|c|c|}
\hline Patient & M.M. & Y.K. & J.O. \\
\hline Age/Sex & $36 / \mathrm{F}$ & $37 / \mathrm{F}$ & $28 / \mathrm{F}$ \\
\hline Underlying illness & APL & AML & ALL \\
\hline $\begin{array}{l}\text { Time from start of the } \\
\text { last course of anti- } \\
\text { leukemic therapy to onset }\end{array}$ & 18 days & 24 days & 21 days \\
\hline $\begin{array}{l}\text { Granulocyte count } \\
\text { at onset }\end{array}$ & $110 / \mu 1$ & $0 / \mu 1$ & $0 / \mu 1$ \\
\hline $\begin{array}{l}\text { Subsequent changes } \\
\text { in granulocyte count*1 }\end{array}$ & Increased & Increased & Increased \\
\hline $\begin{array}{l}\text { Hematologic response } \\
\text { to antileukemic therapy }\end{array}$ & $\mathrm{CR}$ & $\mathrm{CR}$ & $\mathrm{CR}$ \\
\hline Primary infectious focus & Periodontitis & Periodontitis & $\begin{array}{l}\text { Oropharyngeal } \\
\text { mucositis }\end{array}$ \\
\hline Temperature at onset & $38.9^{\circ} \mathrm{C}$ & $38.9^{\circ} \mathrm{C}$ & $38.5^{\circ} \mathrm{C}$ \\
\hline \multicolumn{4}{|l|}{ Complications } \\
\hline Bacteremic shock & - & - & - \\
\hline DIC & - & - & - \\
\hline $\begin{array}{l}\text { Serum protein level } \\
\text { at onset }\end{array}$ & $6.5 \mathrm{~g} / \mathrm{dl}$ & $6.6 \mathrm{~g} / \mathrm{dl}$ & $5.0 \mathrm{~g} / \mathrm{dl}$ \\
\hline Prior antibiotics*2 & $\mathrm{FOM}+\mathrm{GM}$ & $\mathrm{CMZ}+\mathrm{GM}$ & $\mathrm{PIPC}+\mathrm{CAZ}+\mathrm{GM}$ \\
\hline Antibiotic therapy & $\mathrm{IPM} / \mathrm{CS}+\mathrm{GM}$ & $\mathrm{PIPC}+\mathrm{GM}$ & $\mathrm{IPM} / \mathrm{CS}+\mathrm{CAZ}+\mathrm{GM}$ \\
\hline Outcome & Recovered & Recovered & Recovered \\
\hline
\end{tabular}

Abbreviations : APL, acute promyelocytic leukemia ; AML, acute myelogenous leukemia ; ALL, acute lymphocytic leukemia ; CR, complete remission; DIC, disseminated intravascular coagulation ; FOM, fosfomycin ; GM, gentamicin ; CMZ, cefmetazole ; PIPC, piperacillin ; CAZ, ceftazidime ; and IPM/CS, imipenem/cilastatin.

${ }^{* 1}$ Rise of at least $100 / \mu 1$ in granulocyte count at 14 days after onset. Recombinant human granulocyte colony-stimulating factor was administered subcutaneously at a daily dose of $75 \mu \mathrm{g}$ /body prior to the onset of bacteremia in Case J.O.

${ }^{* 2}$ Antibiotics before positive blood cultures were obtained.

intensive induction chemotherapy with resultant profound granulocytopenia and complained of oral pain so severe as to make opening the mouth difficult. Exacerbation of previously asymptomatic periodontitis occurred in two patients, while severe oral mucositis associated with chemotherapy was observed in the other one. Antibiotic therapy was started on an empirical basis. Blood cultures grew C. sputigena after four to five days of incubation. Two isolates showed $\beta$-lactamase production, and the other, a non- $\beta$-lactamaseproducing one, was obtained from a patient (M.M.) who did not receive a $\beta$-lactam antibiotic because of a history of allergy to cefoperazone. Prior antibiotic treatment thus proved ineffective. However, all patients showed clinical improvement after the institution of appropriate therapy in association with bone marrow recovery. The clinical picture seemed to be similar to that of bacteremia due to any other gram-negative organism. Neither shock nor coagulopathy supervened.

\section{Bacteriological Studies Materials and Methods}

\section{Blood Cultures}

The blood sample $(5-10 \mathrm{ml})$ was equally inoculated into two kinds of culture bottles: Liquoid Blood Culture Bottles TSB and Thio (Roche) (tryptic soy broth and thioglycolate medium, respectively), which were incubated at $37^{\circ} \mathrm{C}$ for at least seven days.

\section{Tests for Biochemical Characterization of Capnocytophaga Isolates}

The three blood culture isolates were identified, at the generic level, as Capnocytophaga species by 
conventional methods ${ }^{1,9,10)}$ as well as by the RapID ANA II System ${ }^{\circledR}$ (Innovative Diagnostic Systems, Atlanta, Georgia), which was used according to the manufacturer's directions. The agar media used were trypto-soy agar (Eiken) supplemented with 5\% sheep blood (TS-blood agar and chocolate agar), MacConkey agar (Eiken) and GAM agar (Nissui). Incubation temperature was $37^{\circ} \mathrm{C}$, except that growth was tested at $42^{\circ} \mathrm{C}^{10)}$. GasPak Anaerobic Systems ${ }^{\circledR}(\mathrm{BBL})$ were used to create anaerobic and capneic $\left(5 \% \mathrm{CO}_{2}\right)$ conditions. The latter atmosphere was achieved by the use of jars without catalysts.

For species delineation of the Capnocytophaga isolates, additional biochemical tests were carried out. Fermentation tests for carbohydrates (glucose, lactose, mannitol, sucrose, maltose, xylose, arabinose, cellobiose, glycerol, raffinose, rhamnose, salicin, sorbitol and trehalose) were performed using the API$20 \mathrm{~A}^{\circledR}$ system for the identification of anaerobes (API Systems S.A., France) according to the manufacturer's directions. Acid production from and/or hydrolysis of other carbohydrates (fructose, galactose, dextran and starch) were studied according to the description in the Anaerobe Laboratory Manual of Virginia Polytechnic Institute ${ }^{11}$, using GAM semisolid medium (Nissui) as a basal medium. The isolates were tested for gelatin and starch hydrolysis and nitrate reduction by the methods described in Cowan and Steel's Manual ${ }^{12)}$. Major acid end products of metabolism in GAM semisolid glucose medium (Nissui) were analyzed by gas-liquid chromatography ${ }^{11)}$.

\section{Deoxyribonucleic Acid (DNA) Base Composition}

Mol-percent guanine and cytosine $(\% \mathrm{G}+\mathrm{C})$ was determined by high-performance liquid chromatography ${ }^{13)}$.

\section{DNA Homology}

Capnocytophaga isolates were speciated on the basis of relative homology values as compared with the type strain of each species. The microplate DNA-DNA hybridization method described by Ezaki et al. ${ }^{14)}$ was used to demonstrate DNA homology. The hybridization experiment was carried out at $50^{\circ} \mathrm{C}$ for two hours. Reported results are the average of four such experiments. When the type strain and clinical isolates showed more than $70 \%$ DNA homology, they were considered to belong to the same species. The type strains used were Capnocytophaga ochracea ATCC 27872, C. sputigena ATCC 33612, Capnocytophaga gingivalis ATCC 33624, and Capnocytophaga cynodegmi ATCC 49044.

\section{Antimicrobial Susceptibility}

Susceptibility testing on TS-blood agar was performed in a capneic atmosphere by the triple disk method using Tridisks (Eiken). After 72 hours of incubation at $37^{\circ} \mathrm{C}$, the results were expressed in a four-grade rating of sensitivity from - to $\mathrm{H}$. In addition, susceptibility to vancomycin was determined by the Kirby-Bauer method ${ }^{15)}$ using Sensi-Disc (BBL). The results were classified into three categories of susceptibility: resistant (R), intermediate (I) and sensitive (S).

Production of $\beta$-lactamase was determined by the chromogenic cephalosporin (nitrocefin) method using Cefinase (BBL).

\section{Results}

\section{Cultural Findings of Capnocytophaga Isolates}

Growth in the blood culture bottles became visible after four to five days of incubation in all three cases.

Morphological and physiological characteristics of the three isolates are shown in Table 2. On TSblood agar, they grew equally well in a capneic and an anaerobic atmosphere. In contrast, they did not grow on GAM agar in a capneic atmosphere, although active anaerobic growth was seen on the same agar. However, capneic growth on GAM agar was obtained only after a passage on TS-blood agar under the same conditions. Gliding colonies, whether on TS-blood agar or on GAM agar, were easily observed by oblique 
Table 2 Characteristics of three blood culture isolates*1

\begin{tabular}{|c|c|c|c|}
\hline & Reaction & & Reaction \\
\hline Gram reaction & - & Acid from & \\
\hline Fusiform or & & Glucose & + \\
\hline rod-shaped cells & + & Glycerol & - \\
\hline Colony pigmentation & & Lactose & + \\
\hline (yellow orange) & + & Maltose & + \\
\hline Bitter almond odor & + & Mannose & + \\
\hline Gliding motility & + & Raffinose & + \\
\hline Growth at $37^{\circ} \mathrm{C}$ on & & Sorbitol & - \\
\hline Blood agar & & Sucrose & + \\
\hline In air & $-* 2$ & Trehalose & - \\
\hline $\mathrm{Air}+5 \% \mathrm{CO}_{2}$ & + & Xylose & - \\
\hline GasPak atmosphere & + & Arabinose & $+(1),-(2)$ \\
\hline Chocolate agar & + & Mannitol & $+(1),-(2)$ \\
\hline GAM agar & $+* 3$ & Melezitose & $+(1),-(2)$ \\
\hline MacConkey agar & - & Rhamnose & $+(1),-(2)$ \\
\hline Growth at $42^{\circ} \mathrm{C}$ & + & Cellobiose & $+(2),-(1)$ \\
\hline Oxidase & - & Salicin & $+(2),-(1)$ \\
\hline Catalase & - & Fructose & - \\
\hline Urease & - & Galactose & - \\
\hline Indole & - & Dextran & - \\
\hline Nitrate reduction & + & Starch & + \\
\hline Hydrolysis of & & Acid end products & AS(iv)*4 \\
\hline Esculin & + & Genus suggested by & \\
\hline Starch & $-(2),+(1)$ & RapID ANA II System: & \\
\hline Gelatin & - & \multicolumn{2}{|c|}{ Capnocytophaga species } \\
\hline
\end{tabular}

${ }^{* 1}$ Symbols : - , all isolates were negative; + , all isolates were positive. When different reactions occurred in different isolates, figures in parentheses indicate no. of isolates which showed their respective symbols.

${ }^{* 2}$ Aerobic subculture yielded some small, non-spreading colonies only after 72 to 96 hours of incubation.

${ }^{* 3}$ Capneic growth was obtained only after at least one passage on TS-blood agar in air with $5 \% \mathrm{CO}_{2}$, although anaerobic growth was always active.

${ }^{* 4}$ Fatty acids were detected by gas-liquid chromatography (GLC). Capital and small letters indicate major and minor peaks, respectively.

A : acetic acid; S : succinic acid; and iv : isovaleric acid. GLC analysis of cultures from one patient (Y.K.) revealed trace amounts of isobutyric acid as well.

illumination. Aerobic culture on TS-blood agar yielded a growth of small, yellow-orange,non-gliding colonies after 72 to 96 hours of incubation. Gram staining showed a morphological change from rod-shaped cells in younger cultures of 24 to 48 hours' incubation to fusiform cells in older cultures of more than 48 to 96 hours' incubation, irrespective of the atmospheric condition, whether capneic or anaerobic. Curved forms were also present in small numbers.

\section{Species Differentiation}

Because of the phenotypical similarity of Capnocytophaga species, it proved difficult to speciate the three isolates by conventional techniques used in most hospital microbiology laboratories (Table 2.) In contrast, DNA homology studies identified all isolates as C. sputigena (Table 3).

\section{Antimicrobial Susceptibility}

The susceptibility of the three isolates to 21 antimicrobial agents is listed in Table 4 . Among the $\beta$-lactam antibiotics tested, clavulanic acid/amoxicillin, cefotaxime and imipenem proved active against all 
Table 3 Genomic speciation of Capnocytophaga isolates

\begin{tabular}{lccc}
\hline \multicolumn{1}{c}{ Isolate } & M.M. & Y.K. & J.O. \\
\hline $\begin{array}{l}\text { DNA base composition*1 } \\
\text { \%G }+ \text { C }\end{array}$ & 38.7 & 38.8 & Not done \\
DNA homology*2 & & & \\
$\quad$ Percent hybridization & & & \\
with DNA from & 60 & 25 & 53 \\
C. ochracea ATCC 27872 & 100 & 100 & 85 \\
C. sputigena ATCC 33612 & 2 & 3 & 36 \\
C. gingivalis ATCC 33624 & & & 15 \\
C. cynodegmi ATCC 49044 & 0 & 0 & \\
$\quad$ Escherichia coli K-12 & & & 0 \\
$\quad$ Salmon-sperm DNA & C. sputigena & C. sputigena & C. sputigena \\
Genomic speciation &
\end{tabular}

${ }^{* 1}$ Mol-percent guanine and cytosine $(\% \mathrm{G}+\mathrm{C})$ was determined by highperformance liquid chromatography ${ }^{13)}$.

${ }^{* 2}$ Relative homology values were determined by the microplate hybridization method $^{14)}$.

Table 4 In vitro susceptibility of $C$. sputigena isolates to antimicrobial agents

\begin{tabular}{|c|c|c|c|}
\hline Isolate & M.M. & Y.K. & J.O. \\
\hline $\mathrm{ABPC} * 1$ & m & m & - \\
\hline CVA/AMPC & m & m & m \\
\hline CBPC & m & H & + \\
\hline PIPC & m & m & - \\
\hline CEZ & m & + & - \\
\hline $\mathrm{CMZ}$ & m & + & m \\
\hline $\mathrm{CPZ}$ & m & + & - \\
\hline $\mathrm{SBT} / \mathrm{CPZ}$ & H & m & H \\
\hline СTX & H & m & m \\
\hline $\mathrm{CAZ}$ & m & H & - \\
\hline LMOX & H & H & H \\
\hline IPM & H & H & m \\
\hline $\mathrm{AZT}$ & m & H & $H$ \\
\hline FOM & - & - & - \\
\hline GM & + & H & H \\
\hline AMK & + & $H$ & H \\
\hline MINO & m & m & H \\
\hline
\end{tabular}

CLDM
CL

isolates, two of which gave a positive nitrocefin test. The activity of other $\beta$-lactam agents varied depending largely upon the $\beta$-lactamase-producing ability of the isolates tested. One of the $\beta$-lactamaseproducing isolates proved resistant to both piperacillin and ceftazidime, either of which is currently used in combination with an aminoglycoside for the treatment of febrile patients with granulocytopenia. Moreover, all isolates were susceptible to clindamycin, minocycline, vancomycin and norfloxacin, while they were resistant to fosfomycin and colistin, and to a lesser extent, to gentamicin and amikacin. Incidentally, the aminoglycosides became less active in anaerobic incubation.

\section{Discussion}

Isolation of Capnocytophaga species from previously sterile sites such as blood is usually considered to 
be a potential clue that the source is oral ${ }^{4,5)}$, since the organisms are typical components of the oral microflora ${ }^{1 / 3)}$. Oropharyngeal mucosal breakdown as a consequence of intensive chemotherapy promotes access of the resident flora to deeper tissues. On the other hand, exacerbation of previously asymtomatic periodontal disease has recently been noted to occur with increasing frequency in patients with acute leukemia receiving induction chemotherapy, in contrast to the marked decrease in the number of lower alimentary tract infections ${ }^{6}$. In such clinical settings, the incidence of capnophilic and anaerobic bacteremia originating from the oropharynx is inferred to have increased in granulocytopenic patients, especially those with hematologic malignancy ${ }^{1,4,8)}$.

The empiric antibiotic regimen currently recommended by the European Organization for Research on Treatment of Cancer consists of ceftazidime plus amikacin ${ }^{16)}$, both of which have little or no activity against most of the capnophilic and anaerobic isolates from the blood of granulocytopenic patients ${ }^{4,17)}$. An increasing frequency of $\beta$-lactamase-producing Capnocytophaga isolates has been noted in recent years ${ }^{4,17}$, as already reported for Bacteroides species ${ }^{7,8}$. Many of the antibiotics effective against the latter are active against the former ${ }^{4)}$. Therefore, the empiric use of antibiotics with anti-anaerobic activity, such as imipenem and clindamycin, may be justified when granulocytopenic patients with severe chemotherapyinduced mucositis or acute exacerbation of periodontal disease develop a persistent fever of unknown $\operatorname{origin}^{4,7)}$.

Because of the phenotypical resemblance of Capnocytophaga species ${ }^{9,10)}$, it seems impossible in practice to identify clinical isolates on a species level by the conventional biochemical tests used in most hospital microbiology laboratories ${ }^{10,18,19)}$. This is true of the distinction between C. sputigena and C. ochracea, although tests for starch and gelatin hydrolysis have been reported to be helpful in distinguishing these two species ${ }^{1)}$. As stated by Williams et al. $^{18)}$ and Speck et al. ${ }^{19)}$, therefore, DNA homology studies are considered indispensable for species differentiation of Capnocytophaga isolates.

\section{References}

1) Holt, S.C. \& Kinder, S.A.: Capnocytophaga. In Bergey's Manual of Systematic Bacteriology. (Staley, J.T. ed.) p. 2050-2058, Williams \& Wilkins, Baltimore, 1989.

2) Newman, M.G. \& Sims, T.N.: The predominant cultivable microbiota of the periodontal abscess. J. Periodontol. 50: 350-354, 1979.

3) Holdeman, L.V., Moore, W.E.C., Cato, E.P., Burmeister, J.A., Palcanis, K.G. \& Ranney, R.R.: Distribution of Capnocytophaga in periodontal microfloras. J. Periodont. Res. 20: 475-483, 1985.

4) Baquero, F., Fernándes, J., Dronda, F., Erice, A., Pérez de Oteiza, J., Reguera, J.A., \& Reig, M.: Capnophilic and anaerobic bacteremia in neutropenic patients: an oral source. Rev. Infect. Dis. 12 (Suppl. 2): S157-S160, 1990.

5) Parenti, D.M. \& Snydman, D.R.: Capnocytophaga species: infections in nonimmunocompromised and immunocompromised hosts. J. Infect. Dis. 151: 140-147, 1985.

6) Overholser, C.D., Peterson, D.E., Williams, L.T. \& Schimpff, S.C.: Periodontal infection in patients with acute nonlymphocytic leukemia. Prevalence of acute exacerbations. Arch. Intern. Med. 142: 551-554, 1982.

7) Fainstein, V., Elting, L.S. \& Bodey, G.P.: Bacteremia caused by non-sporulating anaerobes in cancer patients. Medicine 68: 151-162, 1989.

8) Funada, H., Machi, T. \& Matsuda, T.: Anaerobic bacteremia in patients with hematologic malignancy. KenkiseikinKansensho-Kenkyu (J. Jpn. Assoc. Anaerobic Infect. Res.) 17: 12-23, 1987.

9) Socransky, S.S., Holt, S.C., Leadbetter, E.R., Tanner, A.C.R., Savitt, E. \& Hammond, B.F.: Capnocytophaga: new genus of gram-negative gliding bacteria. III. Physiological characterization. Arch. Microbiol. 122: 29-33, 1979.

10) Kristiansen, J.E., Bremmelgaard, A., Busk, H.E., Heltberg, O., Frederiksen, W. \& Justesen, T.: Rapid identification of Capnocytophaga isolated from septicemic patients. Eur. J. Clin. Microbiol. 3: 236-240, 1984.

11) Holdeman, L.V., Cato, E.P. \& Moore, W.E.C. (ed.): Anaerobe Laboratory Manual, 4th ed. Virginia Polytechnic Institute Anaerobe Laboratory, Blacksburg, Va., 1977.

12) Cowan, S.T.: Cowan and Steel's Manual for the Identification of Medical Bacteria, 2nd ed., Cambridge University Press, London, 1974. 
13) Kaneko, T., Katoh, K., Fujimoto, M., Kumagai, M., Tamaoka, J. \& Katayama-Fujimura, Y.: Determination of the nucleotide composition of a deoxyribonucleic acid by high-performance liquid chromatography of its enzymatic hydrolysate: a review. J. Microbiol. Methods 4: 229-240, 1986.

14) Ezaki, T., Hashimoto, Y. \& Yabuuchi, E.: Fluorometric deoxyribonucleic acid-deoxyribonucleic acid hybridization in microdilution wells as an alternative to membrane filter hybridization in which radioisotopes are used to determine genetic relatedness among bacterial strains. Int. J. Syst. Bacteriol. 39: 224-229, 1989.

15) Bauer, A.W., Kirby, W.M.M., Sherris, J.C. \& Turck, M.: Antibiotic susceptibility testing by a standardized disk method. Am. J. Clin. Pathol. 45: 493-496, 1966.

16) The EORTC International Antimicrobial Therapy Cooperative Group: Ceftazidime combined with a short or long course of amikacin for empirical therapy of gram-negative bacteremia in cancer patients with granulocytopenia. $\mathrm{N}$. Engl. J. Med. 317: 1692-1698, 1987.

17) Arlet, G., Sanson-Le Pors, M-J, Casin, I.M., Ortenberg, M. \& Perol, Y.: In vitro susceptibility of 96 Capnocytophaga strains, including a $\beta$-lactamase producer, to new $\beta$-lactam antibiotics and six quinolones. Antimicrob. Agents Chemother. 31: 1283-1284, 1987.

18) Williams, B.L., Hollis, D. \& Holdeman, L.V.: Synonymy of strains of Center for Disease Control group DF-1 with species of Capnocytophaga. J. Clin. Microbiol. 10: 550-556, 1979.

19) Speck, H., Kroppenstedt, R.M. \& Mannheim, W.: Genomic relationships and species differentiation in the genus Capnocytophaga. Zbl. Bakt. Hyg. A 266: 390-402, 1987.

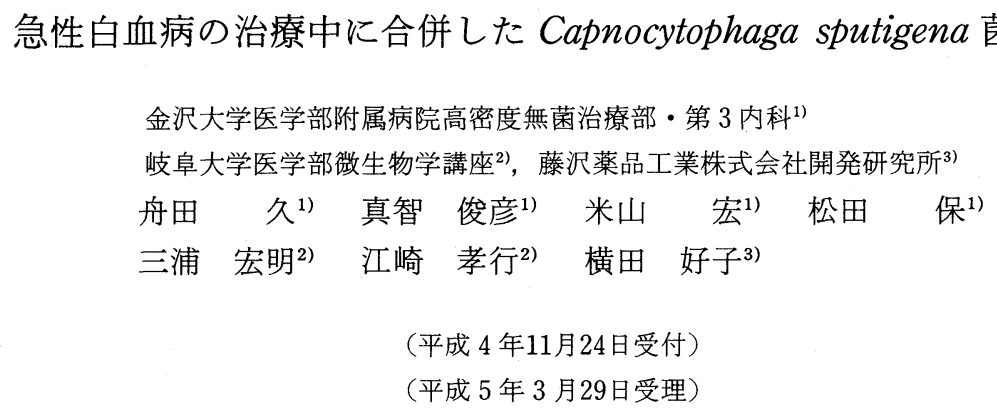

要 旨

過去 3 年間(1989 1991年)に, Capnocytophaga

菌血症が 3 例の急性白血病の治療中に発症した。 侵入門戸は口腔内病変（歯周炎や重症の粘膜炎） と考えられた。血液から分離された 3 菌株はデオ キシリボ核酸 (DNA) の相同性からCapnocytophaga sputigena と同定された。しかし, Capnocytophaga の生物学的性状の類似性から, 分離 菌株の菌種を通常の臨床細菌学的検査法で同定す ることは困難であった。血液分離菌は嫌気性菌に
通常抗菌力をもつ抗生物質の大部分に感性を示し た. $\beta$-ラクタマーゼ産生が 2 菌株に認められ，こ のらちの 1 菌株は顆粒球減少患者の発熱時に経験 的に使用されることの多いピペラシリン (piperacillin) とセフタジジム (ceftazidime) の両薬に 耐性であった。それゆ光, 抗腫瘍薬治療による重 症の口腔粘膜炎や歯周炎の急性増悪をみる顆粒球 減少患者の発熱時にはイミペネム (imipenem) や クリンダマイシン (clindamycin) の使用が考慮さ れるべきである。 